\title{
Workability and Well-Being at Work Among Cut-To-Length Forest Machine Operators
}

\author{
Heli Kymäläinen, Juha Laitila, Kari Väätäinen, Jukka Malinen
}

\begin{abstract}
This study assessed the situation of Finnish cut-to-length (CTL) machine operators' work well-being with workability index (WAI), investigated CTL machine operators' lifestyle habits, and collected operators' good practices to maintain and promote well-being and vitality at work. A questionnaire was conducted in electronic form, including questions concerning background information, work environment, work organisation, well-being at work and free time, and workability index. Mean WAI among respondents was 42.2 points (max. 49) falling into the rank "good ", while the current workability compared with the lifetime best was 8.2 (range $0-10)$. WAI was strongly impacted by age $(p<0.000)$, the score declined during ageing, and standard deviation grew. The results were in line with previous WAI studies. Statistic differences were found between youngest age group (age $\leq 25)$ versus all others. Compared to other studies and occupational groups, CTL machine operators' WAI was average. Operators revered independent nature of work and forest as a working environment, thus promoting and maintaining well-being at work. Furthermore, breaks during work shift, with or without physical exercise, was recognised to ensure and retain vitality and concentration at work.
\end{abstract}

Keywords: well-being at work, workability, workability index, CTL machine operator, CTL harvesting

\section{Introduction}

Employees' well-being at work manifests itself by one's better commitment to the work and fluent collaboration with co-workers but also the quality and productivity of work (Puttonen et al. 2016). As shown in studies (Kuoppala et al. 2008, Vänni et al. 2012, Ahola et al. 2018), employees' well-being at work and workability impacts e.g. productivity, atmosphere among staff and sick leaves. Thus, employees' wellbeing at work is one of the key resources that a thriving and profitable organisation can have.

Well-being at work is composed of the joint effect of several factors in and outside of work, and it can be promoted in different ways. Rauramo (2009) defines steps for well-being at work based on the theory of Maslow's hierarchy, the five-tier model of human needs where the needs lower down in the hierarchy must be satisfied before individuals can attend to needs higher up. In the Rauramo's (2009) theory of well-being at work, the steps from the bottom upwards are:

$\Rightarrow$ psychological basic needs

$\Rightarrow$ need for security

$\Rightarrow$ need for affinity and sense of solidarity

$\Rightarrow$ need for appreciation

$\Rightarrow$ need to fulfil oneself.

Well-being at work involves satisfying work that meets one's psychological needs. Satisfying work can create circumstances that encourage one's full effort and contribution towards work. In return, work can offer meaningful experiences and sensible environment, thus creating enrichment processes and gain spirals (Hakanen 2011). Overall satisfying work can lead to strong work engagement. According to Schaufeli et al. (2002) work engagement consists of three elements: vigour, dedication, and absorption towards work. It is positively related to e.g. overall satisfaction of life (Schaufeli et al. 2006), self-assessed 
health (Hakanen and Lindbohm 2008) and workability (Hakanen et al. 2006), and negatively to intentions of quitting one's job and early retirement (Parzefall and Hakanen 2010). Having a long-lasting effect, work engagement can reflect positive experience of life in general up to three years ahead (Hakanen et al. 2011).

Well-being at work encompasses the concept of workability that determines individuals' mental and physical resources to perform one's work. Workability is a complex issue covering not only different objectively measurable capacities, but also aspects like education, knowledge, skill, experience, and motivation (Ilmarinen and Tuomi 1992). Finnish Institute of Occupational Health (FIOH) has gathered all aspects to the »Workability House", that sums up factors in and outside of working life giving a wide picture of workability paradigm (Ilmarinen et al. 2005). House has 4 floors, each floor representing one dimension of workability. The first three floors, 1) health and functional capacities, 2) competence, 3) values, attitudes and motivation, signify employee's personal aspects, e.g. one's foundation of well-being. The fourth floor »work, work community and leadership « represents the work itself. In addition to the house, there are also surroundings, the framework of our working life. Altogether workability may be seen as a balance between the demands of work and individual's resources (Arvidson 2013). As they are constantly changing, people search for an optimal balance throughout their entire work life (Ilmarinen 2009).

Work environment and work culture of Finnish timber supply chain has been strongly adjusted to the customer's needs for precision and quality (Uusitalo 2005). Timber harvesting has been largely based on small-scale contractors where entrepreneurs usually own 1-3 forest machine(s) or forest machine chains (cut-to-length (CTL) harvester and forwarder) and the entrepreneur himself/herself is contributing to the every-day operational work. Since the beginning of 2000 , timber harvesting sector has organised itself in bigger units forming the so called »diversified independent contractors « (Rekilä and Räsänen 2008, Ovaskainen and Pajuoja 2020). Diversified independent contractors can be e.g. entrepreneurs who have increased and widened their business, or several small-scale contractors joint together. However, there are still small-scale harvester entrepreneurs working in the supply chain as contractors or subcontractors. Acting as timber suppliers, harvester contractors are responsible to fulfil the requirements of primary wood processing industry such as quality and quantity of raw material, but also for issues relating to timetables, silvicultural results, and various environmental as- pects (Nurminen et al. 2009). Industry requirements for raw material are very precise concerning quantities, bucking and timber assortments, and timing. Especially valuable timber assortments such as veneer logs, logs and poles have precise delivery quantities that vary due to seasons and market situations.

In Finland, the wood-harvesting technology and execution is based on mechanised cut-to-length method i.e. machine operator fells, delimbs and bucks the stems at the stump by a harvester, and logs are forwarded to roadside by a forwarder. CTL machine operator's work is demanding and responsible, requiring multiple complex decisions to be taken repeatedly and rapidly (Häggström 2015). The routine work of CTL machine operator is independent and rather monotonous, including long periods of sitting and repetitive, short-cycle movement patterns, up to 4000 control inputs per hour (Gellerstedt 2002). Operators are often afflicted by overload injuries to the neck, arms and cervical spine (Lagerstrom et al. 2019, Gerasimov and Sokolov 2014, Jack and Oliver 2008, Rehn et al. 2002). Productive CTL work also demands wide cognitive capacity including spatial perception, coordination, comprehensive perception, and wide use of memory functions (Ovaskainen and Heikkilä 2007). Moreover, during harvesting work, the private forest owners, i.e. timber sellers, are interested in profitable bucking (e.g. more valuable saw logs, less low-valued pulpwood), and customers, i.e. timber buyers, expect high-quality raw material from bucking. Thus, the machine operator's expertise has an important role in successful timber supply chain and single operator's work contribution has also considerable effect on productivity and result in small-scale contractor's business. In addition, work shifts, and commutes can be lengthy and in Finland the winter season with short daylight period is rather long (Heinikoski and Mehtälä 2016). Hence, there is a great pressure on forest machine operators' recovery and well-being based on the characteristics of the work.

As well as other industries, timber harvesting work has been affected by development of internet and web communications that has enabled industrial internet (ETLA 2015). Industrial internet has intoduced realtime reporting and surveillance in the timber harvesting operations. Operators are required to manage an increasing amount of IT-skills alongside heavy machinery technology and forestry competence. Not only reporting, but operators are also e.g. expected to predict the incoming raw material volumes to the roadside and execute quality controls via enterprises' resource planning systems (Nieminen 2015). Operators' opinions about data systems are divided. According 
to Siukola et al. (2018), half of the operators feel that data systems ease the work, while the other half experience they impede working. This dimension of harvesting work includes processing, managing and producing information that is essential for the functional timber procurement chain, its predictability and productivity. Beyond expertise, the accurate and timely information flow also strongly relates to the machine operators' (pro)activity, motivation, and workability (Siukola et al. 2018, Väätäinen et al. 2012).

CTL harvesting machines are expensive and high productivity is expected to compensate large investment. Stem size is one of the most significant factors influencing CTL harvester's productivity (e.g. Jiroušek et al. 2007, Erikson and Lindroos 2014), but naturally multiple environmental variables affect harvesting productivity as well (Erikson and Lindroos 2014). Being difficult to alter operational environment, the attention focuses on machinery and operator. According to Purfürst (2010) learning curve of CTL machine operators, it takes on average 8 months to end the learning phase and hit the first plateau in productivity. After the plateau, productivity still increases slowly, but steadily, up to 15 years of experience (Malinen et al. 2018). In general, studies show that one's productivity declines over age due to reduction in the cognitive abilities such as perception speed, reasoning abilities, memory, and learning (Carone et al. 2005, Skirbekk 2004, Skirbekk et al. 2011). Over time, there are environmental and personal variation from harvesting conditions to operator's personal vitality (Purfürst 2010). However, there is no clear indication of a drop in the productivity among forest machine operators due to the high demand of work expertise that accumulates over time. Operators' ageing reduces merely the peak productivity of work (Malinen et al. 2018). Thus, embracing well-being at work and workability ameliorate the commitment and perseverance of work, enabling professional operators to develop and even achieve long careers.

Prolonging work careers is also considered beneficial in governance level. According to Eurostat's publication Ageing Europe (2020), the population in the European Union (EU) will decrease from 446.8 million to 441.9 million during the period 2026-2050. At the same time, the population of older people (65 years or more) will increase significantly from 90.5 million to 129.8 million and there will be $13.5 \%$ fewer people aged less than 55 years living in the EU. Economic dependency ratio in Europe will increase substantially during the next 30 years adding pressure to prolonging work careers (Carone et al. 2005, Shemeikka et al. 2017). Forest machine operators' sedentary work positions together with whole body vibration create a physical challenge for lengthening careers as sitting times and whole-body vibration have been shown to cause a health risk (e.g. Katzmarzyk et al. 2009, Robert and Michele 2008). Policymakers have recognised that job satisfaction plays an important role in relation to extending work lives. Alongside remuneration, job satisfaction can be linked to a wide range of other factors, including working conditions, job security, support, and recognition at work (European Comission 2017). Workability and well-being at work provides foundation for prolonged careers as well as better resources for lifelong learning, which also seems to relate to extended careers (Serban 2012).

Carrying out well-being at work and workability improvements, organisations often focus on organisational development, e.g. management and leadership, promotions and career opportunities of staff, updating job descriptions and improving solidarity and communications (Repo et al. 2015, Siukola et al. 2018). Thus, the profound factors and needs related to individual's well-being at work are ignored (work ability house floors 1-3). In addition, the nature of this kind of organisational improvements rarely fits in timber harvesting companies as the harvesting work is extremely independent and job descriptions are rather inflexible (Häggström 2015). Understanding of workability as a large issue enhances employees' quality of life, but also helps organisations to improve productivity, recruit new staff and keep employees from resining (Mylek and Schirmer 2015).

Independent work with expensive machinery, responsibility of productivity, quality of work and raw material, long working hours, monotonous work, high level of expertise, tight timelines, and variation in operational environment are all recognised as work characteristics of CTL harvesting (Heinikoski and Mehtälä 2016, Kääriäinen 2017, Vihottula 2010). Timber harvesting practises have changed from physical work towards sedentary, more tortuous, and mentally demanding work thus putting great pressure on the operators' well-being at work, workability and recovery. While timber harvesting is based on CTL method in Northern Europe, and increasingly in the other parts of Europe and North America, there is no clear overall picture of the CTL operators' well-being at work and workability. The aim of this study was to assess the Finnish CTL machine operators' (both harvester and forwarder) well-being at work and workability and to determine the workability index (WAI) among them. For wider evaluation and positioning the CTL machine operator's occupation, the study compared the CTL machine operators' WAI to other occupational 
groups. Furthermore, the study looked for good methods and practises among operators for sustaining wellbeing at work and workability.

\section{Materials and Methods}

The study was carried out using an electronic survey (eLomake). The aim was to deliver the survey straightforward to the forest machine operators (not via employers), thus it was conducted through Facebook group »Forest machine operators «(»Metsäkoneenkuljettajat «) that is followed by 9000 people. Most of them are forest machine operators, but also timber harvesting contractors and people interested in timber harvesting. The questionnaire was published in September 2019 and it was available for two weeks.

The survey contained four different subject areas: A) background information, B) work environment and work organisation, C) well-being at work and free time, and D) workability index. Sections $\mathrm{A}$ to $\mathrm{C}$ contained 36 questions, 33 questions had response options, and several questions included open ended alternative beyond ready-made response choices. Three questions were purely open ended. Depending on the question, the amount of response options were limited to one or the respondent had the opportunity to pick several options.

Section A, the background information, contained questions concerning age, work experience and the geographical location where the respondent was working. Section B investigated the work environment and work organisation with questions concerning the specifics of work shifts and working culture, work organisation, and the machinery. Section $C$ investigated the well-being at work, free time and lifestyle habits with questions concerning the psychological workflow, nutrition in and outside of work, breaks during work shift, body care or other benefits provided by employer, physical exercise habits and social relations and support. Furthermore, section $C$ inquired the positive aspects of CTL harvesting work and the means and techniques operators have for keeping up good vitality during work shift.

Section D contained workability index questionnaire. For evaluating one's workability, Finnish Institute of Occupational Health developed Workability Index (WAI) questionnaire (Ilmarinen 1991, Tuomi 1997). Primarily it was developed for research, but according to Ilmarinen (2007), the method has spread to various countries, both for (medical) practice and as a research tool, and it is by far the most used and wellaccepted instrument to measure workability (Van der
Berg et al. 2009). The validity and reliability of the WAI has been assessed in correlation analyses (Ilmarinen 2007), Radkiewich et al. (2005) and de Zwart et al. (2002) have studied the validity of WAI. The WAI and all its items predict reliably work disability, retirement, and mortality (Ilmarinen and Tuomi 2004).

WAI consists of seven indicators that help answer the question of how well or healthy the employees are currently and expected to be in the near future (Kettunen 2015), and it aims to assess how able employees are to do their work with respect to their work demands, their health and mental resources. Workability Index (WAI) consists of seven sections having 11 questions. Out of 11 questions, 8 have three-, five-, or six-level likert-scale (Rautio and Michelsen 2013). Sections focus on worker's i) workability compared to the lifetime best, ii) workability (physical and psychological) in relation to work demands, iii) current medical conditions, iv) disadvantages of medical conditions related to work, v) the number of sick days during past 12 months, vi) worker's personal prediction of future workability, and vii) psychological resources. Each section accumulates points, and the result can vary between 7-49 points. The outcome of the WAI has been divided into four groups according to the final score: poor (7-27 points), moderate (28-36 points), good (37-43 points) and excellent (44-49 points). Moreover, beyond the total WAI score, workability studies also use the first question from the WAI questionnaire to reflect the state of workability: »If assumed that your workability gets ten points when it is at its best. What is your current workability compared to the lifetime best workability? « The scale is from zero to ten, zero means no possibility to work and ten is the best possible workability.

Workability index used in the current study was modified from the original WAI questionnaire. In the original WAI questionnaire, the specific medical conditions are required. In this study, there was no need to know the specific definitions of the possible medical conditions machine operators were suffering; therefore, these questions were left out as the exact medical condition do not affect the WAI score. Instead, only the number of medical conditions that medical expert had diagnosed were required. However, as operators work in relatively static work postures in timber harvesting machines, the respondents were asked to state whether they had any pains, aches or numbness in hands or any part(s) of the spine.

The survey obtained 461 responses by convenience sampling. Due to some imprecision of the answers, finally 438 responses were analysed. Basic characteristics of the data were analysed by standard statistic 
values such as mean, median and mode. Cross tables were also used to clarify data content. WAI was evaluated through different background variables. Since values of answers did not show a normal distribution, the non-parametric Kruskal-Wallis test was used to evaluate WAI. If the test showed statistically significant differences between groups, the Mann-Whitney $U$-test would be used. The statistical significance level of $p<0.05$ was used for all results.

\section{Results}

\subsection{Background Information}

Approximately two thirds of the respondents were 35 years old or younger (Table 1 ). However, work experience was low in the age group 26-35. This indicates that many of the forest machine operators do not get vocational education at the beginning of their careers in their twenties but more likely some years later. This may also indicate that many operators move away from the forest machine operator's career after maximum 5 years of experience. Two thirds $(66.2 \%)$ of respondents were operating CTL harvester and one third $(33.8 \%)$ forwarder.

Table 1 Respondents' age distribution (\%) and work experience $(\%)$ in years

\begin{tabular}{|c|c|c|c|}
\hline Age, years & $\%$ & Work experience, years & $\%$ \\
\hline$\leq 25$ & 33.3 & $0-5$ & 33.8 \\
\hline $26-35$ & 32.0 & $6-10$ & 20.9 \\
\hline $36-45$ & 22.2 & $11-15$ & 18.9 \\
\hline $46-55$ & 9.4 & $16-20$ & 11.8 \\
\hline $56 \leq$ & 3.1 & $>20$ & 13.7 \\
\hline
\end{tabular}

\subsection{Work Environment and Work Organisation}

Forest machine work seems to be rather flexible, $6.7 \%$ reported their work hours were given, others had the possibility to fix them $(60.3 \%)$ or work hours were free $(33.0 \%)$. Forest machine operators tend to have shift work (Table 2). The duration of shift/workday was most likely 8-9 hours, but one third responded that the duration of shift/workday was 10-11 hours. Even if the commutes are long, they are rarely included into the shift duration.

Used machinery was rather new, $65.7 \%$ reported that they were operating maximum five-year old machine and $60.3 \%$ reported that the technical improvements over time had improved their well-being at work. Most advantageous improvements were the reduction of noise $(67.5 \%)$, cabin levelling technologies $(60.7 \%)$ and improved adjustment of temperature $(57.0 \%)$. In addition, there were several mentions of increased capacity of work lights in open-ended answers.

Two meal breaks were most common among respondents, but almost all $(88.8 \%)$ respondents had at least one meal break (Table 3). Planned work breaks other than meal breaks were used by $42.1 \%$ of respondents (Table 4). During other breaks, the most popular activity was to calibrate harvester's head (46.7\%), walk on the work site and review the quality of work and/ or plan the work ahead $(46.3 \%)$ or do machine maintenance $(42.6 \%)$. Altogether $85.2 \%$ of respondents estimated that they had approximately maximum 4 unplanned interruptions during workday (Table 4), e.g. fixing the chain of harvester head or socialising with passers-by. Naturally, this number can change largely depending on the characteristics of the work site. After breaks, planned or unplanned, $55.0 \%$ of respondents reported it was easy to get back to work, while $42.8 \%$ reported it was easy to get back to work »occasionally«.

Table 2 Work arrangements of CTL machine operators by age

\begin{tabular}{|l|c|c|c|c|c|c|}
\hline \multirow{2}{*}{} & \multicolumn{5}{|c|}{ Age, years } \\
\cline { 2 - 7 } & $\leq 25$ & $26-35$ & $36-45$ & $46-55$ & $56 \leq$ & Mean \\
\hline Shift work, \% & 76.5 & 68.7 & 60.4 & 55.8 & 64.3 & 68.1 \\
\hline Daytime job, \% & 23.5 & 31.3 & 39.6 & 44.2 & 35.7 & 31.9 \\
\hline Shift duration 8-9 hours, \% & 49.0 & 61.9 & 73.3 & 60.5 & 66.7 & 60.3 \\
\hline Shift duration 10-11 hours, \% & 40.5 & 34.0 & 22.8 & 30.2 & 33.3 & 33.2 \\
\hline Weekend work - regular, \% & 13.1 & 8.8 & 3.0 & 9.3 & 0.0 & 8.7 \\
\hline Weekend work - occasional, \% & 67.3 & 61.9 & 72.3 & 62.8 & 50.0 & 65.7 \\
\hline
\end{tabular}


Table 3 CTL machine operators' meal breaks during work shift by age

\begin{tabular}{|c|c|c|c|c|c|c|}
\hline \multirow{2}{*}{$\begin{array}{l}\text { Number of meal } \\
\text { breaks, \% }\end{array}$} & \multicolumn{6}{|c|}{ Age, years } \\
\cline { 2 - 7 } & $\leq 25$ & $26-35$ & $36-45$ & $46-55$ & $56 \leq$ & Mean \\
\hline 0 & 2.0 & 2.0 & 5.0 & 0.0 & 7.1 & 2.6 \\
\hline 1 & 26.1 & 19.1 & 10.9 & 11.6 & 0.0 & 18.3 \\
\hline 2 & 47.1 & 42.2 & 37.6 & 25.6 & 28.6 & 40.8 \\
\hline $3 \leq$ & 24.8 & 36.7 & 46.5 & 62.8 & 64.3 & 38.2 \\
\hline
\end{tabular}

Table 4 CTL machine operators' breaks (other than meal) by age

\begin{tabular}{|l|c|c|c|c|c|c|}
\hline \multirow{2}{*}{$\begin{array}{l}\text { Breaks } \\
\text { (other than meal), \% }\end{array}$} & \multicolumn{6}{|c|}{ Age, years } \\
\cline { 2 - 7 } & $\leq 25$ & $26-35$ & $36-45$ & $46-55$ & $56 \leq$ & Mean \\
\hline Yes & 39.9 & 46.3 & 39.6 & 46.5 & 28.6 & 42.1 \\
\hline Occasinally & 47.1 & 41.5 & 46.5 & 34.9 & 57.1 & 44.3 \\
\hline No & 13.1 & 12.2 & 13.9 & 18.6 & 14.3 & 13.5 \\
\hline
\end{tabular}

\subsection{Well-being at Work and Free Time}

Psychological workflow and absorption into work is recognised to be an essential factor in well-being at work. However, $10 \%$ answered that they have troubles to get into workflow in general or after interruptions (Table 5). Audiobooks and talking on the phone (often with colleagues) were greatly appreciated when aiming into good workflow.

Approximately half $(49.8 \%)$ of the respondents have varied and diverse diet (Table 6). Operators aged 46 or older answered more likely to have diverse diet than younger groups. During work shifts the youngest age group (age 25 or under) used energy drinks $(20.0 \%)$, while the older groups consumed merely coffee for stimulant. The older the respondent, the fewer used alcohol. An exception was the youngest group that used less alcohol than the age groups 26-35 and $36-45$. Physical exercise was quite modest in the sample, one fifth replied to have physical exercise at least three times per week and $14.0 \%$ did not have any kind of physical exercise. Age did not seem to play important role in physical activity. As social relations are a

Table $\mathbf{5}$ How easy it is for CTL machine operators to get into workflow by age

\begin{tabular}{|l|c|c|c|c|c|c|}
\hline \multirow{2}{*}{} & \multicolumn{7}{|c|}{ Age, years } \\
\cline { 2 - 7 } & $\leq 25$ & $26-35$ & $36-45$ & $46-55$ & $56 \leq$ & Mean \\
\hline Cannot get into workflow, \% & 3.8 & 7.5 & 10.5 & 10.4 & 28.6 & 7.4 \\
\hline Easy to get into workflow, \% & 16.1 & 18.9 & 30.1 & 37.5 & 35.7 & 22.0 \\
\hline Ease workflow by talking on the phone, \% & 30.9 & 28.9 & 19.6 & 16.7 & 0.0 & 26.1 \\
\hline Ease workflow with audiobooks, \% & 49.2 & 44.8 & 39.9 & 35.4 & 35.7 & 44.5 \\
\hline
\end{tabular}

Table $\mathbf{6}$ Lifestyle habits and social resources of CTL machine operators by age

\begin{tabular}{|c|c|c|c|c|c|c|}
\hline & \multicolumn{6}{|c|}{ Whil, years } \\
\hline & $\leq 25$ & $26-35$ & $36-45$ & $46-55$ & $56 \leq$ & Mean \\
\hline Diverse diet, \% & 41.8 & 48.3 & 58.4 & 58.1 & 64.3 & 49.8 \\
\hline Diverse diet occasionally, \% & 51.6 & 40.8 & 35.6 & 32.6 & 35.7 & 42.4 \\
\hline Exercise 3 times/wk. or more, \% & 21.6 & 17.0 & 24.8 & 16.3 & 7.1 & 19.9 \\
\hline Exercise 2 times/wk., \% & 22.2 & 27.9 & 19.8 & 25.6 & 21.4 & 23.8 \\
\hline Exercise occasionally, \% & 41.2 & 41.5 & 42.6 & 41.9 & 64.3 & 42.4 \\
\hline Enough social relations, \% & 74.7 & 63.5 & 75.3 & 69.1 & 83.3 & 71.0 \\
\hline Somewhat enough social relations, \% & 23.3 & 33.1 & 20.8 & 26.2 & 16.7 & 25.9 \\
\hline
\end{tabular}


Table 7 Well-being at work benefits provided by employer, by age

\begin{tabular}{|c|c|c|c|c|c|c|}
\hline \multirow{2}{*}{ Benefits offered by employer } & \multicolumn{6}{|c|}{ Age, years } \\
\hline & $\leq 25$ & $26-35$ & $36-45$ & $46-55$ & $56 \leq$ & Mean \\
\hline Physical exercise, \% & 19.5 & 18.9 & 28.3 & 18.8 & 7.1 & 17.0 \\
\hline Body care, \% & 7.3 & 8.5 & 12.4 & 12.5 & 7.1 & 4.4 \\
\hline Physical exercise and body care, \% & 4.6 & 5.4 & 8.8 & 7.0 & 0.0 & 5.9 \\
\hline Culture events, etc., \% & 4.9 & 6.7 & 8.0 & 4.2 & 0.0 & 6.6 \\
\hline No benefits offered, \% & 68.3 & 65.9 & 51.3 & 64.6 & 85.7 & 70.1 \\
\hline
\end{tabular}

Table 8 Workability index (WAI) in different age groups

\begin{tabular}{|l|c|c|c|c|c|c|}
\hline \multicolumn{2}{|c|}{} & \multicolumn{5}{|c|}{ Age, years } \\
\hline N & All & $\leq 25$ & $26-35$ & $36-45$ & $46-55$ & $56 \leq$ \\
\hline Mean & 438 & 144 & 140 & 99 & 41 & 41.2 \\
\hline SD & 42.4 & 44.2 & 42.1 & 41.1 & 5.0 & 37.9 \\
\hline Median & 5.0 & 3.4 & 4.8 & 5.8 & 42 & 38.5 \\
\hline Mode & 43 & 45 & 43 & 42 & 39 & 33 \\
\hline
\end{tabular}

vital aspect of well-being, over two thirds replied to have enough social relations and 3.1\% reported that they do not have anyone to talk to about their personal issues.

Altogether 32.6\% reported that well-being at work benefits were provided by their employer (Table 7). Usually these were somewhat related to physical exercise and body care, e.g. free of charge gym membership or massage. To whom these benefits were available, $49.2 \%$ took advantage of them. Most of the respondents $(78.2 \%)$ wished that potential benefits were related to physical exercise and body care. However, $16.2 \%$ reported that there was no need for benefits or services related to well-being at work.

When inquired about good aspects of work in the open-ended question, the most frequently answered themes were independency (145 times), forest nature as operational environment (70 times), forestry as one's own niche and working with heavy and modern machinery (54 times), fixable and flexible working hours (43 times), ability to see outcome of one's own work (39 times), possibility to continuously improve professional skills (32 times) and work community (31 times). For sustaining and promoting workability, physical exercise and decent physical condition, diverse diet, sufficient sleep, strong balance between work and personal life, regular breaks during work shifts combined with brief physical exercises, clean and organised workstation and 4-point harnesses were mentioned.

\subsection{Workability Index (WAI)}

Mean workability index among forest machine operators was 42.4 points falling into the rank "good «. $47.1 \%$ of respondents reached the rank »excellent«, $42.8 \%$ »good « $8.0 \%$ » age, the score of WAI was declining (Table 8). Besides WAI declining, standard deviation (SD) also increased during ageing.

When inquired about the current workability compared with the lifetime best, the mean value of all respondents was 8.2 (Table 9). This value did not decline with age as straightforward as the workability index.

Table 9 Current workability compared with the lifetime best $(0=$ unable to work, $10=$ very good workability $)$

\begin{tabular}{|c|c|c|c|c|c|c|}
\hline Age & $\leq 25$ & $26-35$ & $36-45$ & $46-55$ & $56 \leq$ & Mean \\
\hline & 8.6 & 8.1 & 7.9 & 8.0 & 7.4 & 8.2 \\
\hline
\end{tabular}


Kruskal-Wallis test showed that age impacts strongly on WAI $(p<0.000, d f=4)$. However, when analysed with Mann-Whitney $U$-test between age groups, statistically confirmed differences were between the youngest group (age $\leq 25$ ) versus all others, and between the age groups $26-35$ and $56 \leq$ (Table 10).

Table 10 Statistical differences ( $p$-values) between age groups in Mann-Whitney U-test of WAI

\begin{tabular}{|c|c|c|c|c|c|}
\hline & \multicolumn{5}{|c|}{ Age, years } \\
\hline Age, years & $\leq 25$ & $26-35$ & $36-45$ & $46-55$ & $56 \leq$ \\
\hline $\mathrm{N}$ & 144 & 140 & 99 & 41 & 14 \\
\hline$\leq 25$ & - & $0.000^{* * *}$ & $0.000^{* * *}$ & $0.000^{* * *}$ & $0.000^{* * *}$ \\
\hline $26-35$ & $0.000^{* * *}$ & - & 0.321 & 0.288 & $0.019^{*}$ \\
\hline $36-45$ & $0.000^{* *}$ & 0.321 & - & 0.737 & 0.057 \\
\hline $46-55$ & $0.000^{* * *}$ & 0.288 & 0.737 & - & 0.100 \\
\hline
\end{tabular}

${ }^{*} p<0.05^{* *} p<0.01{ }^{* * *} p<0.001$

\section{Discussion}

Work characteristics of CTL harvesting machine operators are demanding, and mastering the CTL harvesting method requires a wide range of skills and long work experience. The aim of this study was to assess Finnish CTL harvesting operators' (both harvester and forwarder) well-being at work, to find out their workability index (WAI), to compare WAI to other occupational groups, and to look for good practices for maintaining workability. The study was carried out as a questionnaire and it was implemented in electronic form. To reach directly (not via employer) as many CTL harvesting operators as possible, the survey was introduced in Facebook group called $»$ Forest machine operators « (followed by 9000 people, including machine operators, but also timber harvesting contractors and people interested in timber harvesting). The channel provided effective means to introduce the questionnaire to the target group and collect data. Furthermore, electronic survey enabled answering via mobile device, which lowered the threshold of answering. The questionnaire collected 461 answers and 438 answers were approved for final analysis due to some imprecisions. Altogether, the number of responses was higher compared to some timber harvesting questionnaire studies as those made by Siukola et al. (2018) 185-235 answers, Landekić (2013) 67 answers, Rytkönen (2009) 90-103 answers, and Perkiö-Mäkelä et al. (2001) 328 answers.
Previous studies concerning different occupational groups have shown that WAI decreases during ageing (e.g. Monteiro et al. 2006, Pohjonen 2001, Tuomi et al. 1991). The present study supports the same interpretation as the WAI decreased from 42.2 to 37.9 during ageing. It seems that, at young age, WAI was likely to be better, while during ageing the mean declined and standard deviation grew. Agening does not automatically decrease the workability index. According to Ilmarinen (2006), individual differences in workability increases with age, resulting in a declining trend of workability by age. Higher workability is more likely to be met if an employee is able to use his/hers accumulating work expertise and work experince during career, and in practice this is manifested by promotions, career opportunities and changes of work tasks. In CTL harvesting work, the job descriptions are rather inflexible (Häggström 2015), making it difficult to apply a high level of expertise in other tasks outside CTL harvesting work. Furthermore, as overweight, decline in health status (psychological or physical), and the risk of (prolonged) unemployment increase the risk of presenting moderate or poor workability, young age does not unquestionably assure high score in workability index (Lappalainen et al. 2016, El Fassi et al. 2013, Boström et al. 2011).

When evaluating the current workability compared to the lifetime best, a somewhat higher mean (8.2) was obtained in the present study than in other studies in Finland (Table 11). In the study by Rytkönen et al. (2008), occupational groups were somewhat wide, e.g » Forestry « included responses from chain-saw workers, forest machine operators and long-distance

Table 11 Current workability compared to the lifetime best $(0=$ unable to work, $10=$ very good workability) compared with other occupational groups in Finland

\begin{tabular}{|l|c|}
\hline & $\begin{array}{r}\text { Current workability } \\
(0-10)\end{array}$ \\
\hline CTL harvesting operators & 8.2 \\
\hline Forest machine operators & 7.3 \\
\hline $\begin{array}{l}\text { Forestry (inc. manual work, } \\
\text { CTL harvesting and haulage) }\end{array}$ & 7.8 \\
\hline Agriculture $^{2}$ & 7.7 \\
\hline Dockworkers $^{2}$ & 7.8 \\
\hline Construction workers $^{2}$ & 7.8 \\
\hline${\text { Finnish working aged } \text { men }^{3}}^{2}$ & 7.8 \\
\hline
\end{tabular}

${ }^{11}$ Siukola et al. $201{ }^{21}$ Rytkönen et al. $2008{ }^{31}$ Koponen et al. 2017 
drivers. According to the national health study by Koponen et al. (2018), the mean workability among Finnish working aged men was 7.8.

When comparing CTL harvesting operators' mean WAI to other occupational groups internationally (Table 12), operators seem to have higher WAI. Mean WAI of Finnish CTL machine operators was somewhat better than that of forest machine operators in the Croatian private sector (Landekić et al. 2013). Furthermore, Landekić et al. (2013) also pointed out that mental demands are higher and WAI somewhat lower when working in private sector harvesting companies versus state owned companies. Occupational safety and health have been a high priority of the Finnish forest industry, which may have enabled and promoted good and well-functioning working culture. However, these developments and their impacts on workability and safety need further research. In comparison to another occupational group including long periods of sitting, bus drivers, CTL operators seem to have higher WAI.

Table 12 Comparing CTL harvesting operators' mean workability index (WAI) to other occupational groups

\begin{tabular}{|l|c|}
\hline & WAI \\
\hline CTL harvesting operators & 42.4 \\
\hline CTL harvesting operators $^{1}$ & 38.1 \\
\hline Bus drivers $^{2}$ & 36.8 \\
\hline Construction workers $^{3}$ & 38.7 \\
\hline Home care workers $^{4}$ & 37.7 \\
\hline White-collar workers $^{5}$ & 41.1 \\
\hline
\end{tabular}

${ }^{11}$ Landekić et al. $2013{ }^{21}$ Kloimüller et al. $1999{ }^{31}$ Alavinia et al. 2009

${ }^{4)}$ Pohjonen $2001{ }^{5}$ van der Berg et al. 2008

Well-being at work and ergonomics in forestry have been studied during the last decades and the results have reflected the change of work environment, development of technology, techniques, and ergonomics (e.g. Häggström 2015, Ovaskainen 2009, Tynkkynen 2001, Kanninen 1996, 1990, 1989, Asikainen and Harstela 1993, Harstela 1990). Due to the development of technology and digitalisation, timber harvesting work has become more independent and personal contacts with co-workers or supervisors have decreased. Over time, a great number of supervision tasks have shifted further on in the supply chain e.g. to timber harvesting contractors and to machine operators. It is recognised that CTL operators are still exposed to physical strain like whole body vibration, long periods of sitting, and stress injury to spine and arms/hands (e.g. Lagerstrom et al. 2019, Siukola et al. 2018, Häggström 2015, Jack and Oliver 2008). For reducing physical strain and long periods of sitting, respondents reported in the questionnaire e.g. the use of 4-point harnesses in machine seats, and regular breaks during work shifts and brief physical exercises during breaks. Furthermore, clean, and well-organised workstation promoted workflow and sense of easiness. However, ergonomics of machine seats, and ergonomics and adjustability of armrests were most frequently mentioned development areas in machinery.

One of the most important psychological resources that creates intrinsic motivation is sufficient independency and self-regulation that leads to increased enthusiasm and innovative behaviour (Deci and Ryan 2000). Independent nature of work in CTL harvesting was one of the most occurred factors that was expressed in our questionnaire when asked about positive aspects of work. Respondents related the independency to aspects such as responsibility of managing the entirety of work, freedom to plan own work and to perform work without supervision. While the supervision tasks have shifted more from the office supervisors to the field workers (operators), this shift does not seem to be too extensive, hence the independency is still experienced positively. At the same time strongly independent work requires good self-management skills, including the responsibility of work tasks and understanding one's own well-being at work. Further studies concerning personal lifestyle habits and their influence on the CTL harvesting work productivity and workability would be needed. Furthermore, in the responses, independency was emphasised by flexible and fixable working hours. However, the ability to fix shifts may lead to »normalising " weekend work although during high seasons machines tend to run seven days a week. At the same time respondents appreciated highly supportive and likeminded work community. Thus, the balance between independence, relatedness and sense of solidarity is also strongly related to intrinsic motivation (Deci and Ryan 2000).

Meaningful and flowing work in safe and encouraging environment supports and promotes good wellbeing at work and leads to work engagement, which results in good motivation, productivity, and quality of work (Puttonen et al. 2016). In our questionnaire, the following positive aspects of CTL harvesting work were frequently mentioned: forest as an operational environment, ability to see the outcome of own work, 
constant improvement of one's professional skills, and the work with heavy and modern machinery.

While social media provides easy channel to introduce survey, fast means to collect data and convenient access straight to the target group, it has some limitations and contains certain risks. It enables very little control of whom the enquiry is addressed to and how to collect diverse samples of the target population. It is likely that certain age groups that are more familiar and active in social media, are more likely to be represented in the final sample. In addition, there are extremely minor possibilities to sort out answers if the same respondent answers more than once to the survey. Furthermore, when using questionnaire, it is possible that questions may lead to recall bias even though survey themes and questions went through testing before the questionnaire was published.

\section{Conclusions}

According to study results, CTL harvesting machine operators' well-being at work and workability are at least average as compared to some other occupational groups. Workability of CTL harvesting operators seems to be at its best in young operators and declines and disperses during aeging. Independent nature of work and forest as an operational environment supports and promotes well-being at work. Development of machine ergonomics has decreased operators' physical strain over decades, thus CTL harvesting work includes physical stressors like long periods of sitting and demand of a wide range of cognitive skills. Hence CTL harvesting work requires good self-management and understanding of own well-being at work. Operators' daily habits and expertise to organise work influence workability, but the work arrangements and work culture also affect wellbeing at work and workability. Further research is needed to study how the development of the private sector harvesting companies, e.g. socio-economic frame conditions, impacts workability and well-being at work. It is also necessary to study how operators' personal lifestyle choices and habits influence wellbeing at work, workability and productivity regardless of work environment and work characteristics.

\section{Acknowledgments}

This study is a part of the project »CTL machine operators' well-being at work and productivity « funded by Metsämiesten säätiö foundation. Furthermore, the authors gratefully acknowledge the support of the University of Eastern Finland, Natural Resourses Institute Finland and Metsäteho Ltd.

\section{References}

Ahola, S., Eskelinen, J., Heikkilä-Tammi, K., Kuula, M., Larjovuori, R.L., Nuutinen, S., 2018: Digital path to work engagement? Study of the linkage between employee well-being and productivity in a financial service company. CROSSOVER 8/2018, Department of Information and Service Management, Aalto University, Helsinki, 92 p.

Alavinia, S.M., de Boer, A.G.E.M., van Duivenbooden, J.C., Frings-Dresen, M.H.W., Burdorf, A., 2009: Determinants of work ability and its predictive value for disability. Occupational Medicine 59(1): 32-37. https://doi.org/10.1093/occmed/ kqn148

Arvidson, E., Börjesson, M., Ahlborg, G., Lindegård, A., Jonsdottir, I.H., 2013: The level of leisure time physical activity is associated with work ability-a cross sectional and prospective study of health care workers. BMC Public Health 13(1): 1-6. https://doi.org/10.1186/1471-2458-13-855

Asikainen, A., Harstela, P., 1993: Influence of small control levers of grapple loader on muscle strain, productivity and control errors. Journal of Forest Engineering 5(1): 23-28. https://doi.org/10.1080/08435243.1993.10702651

Boström, M., Sluiter, J., Hagberg, M., 2011: Relations between changed self-reported work factors and changed work ability among young male and female adults: a prospective cohort study. Occupational and Environmental Medicine 68(Suppl. 1): A23-A24. http://dx.doi.org.ezproxy.uef.fi:2048/10.1136/ oemed-2011-100382.73

Carone, G., Costello, D., Guardia, N.D., Mourre, G., Przywara, B., Salomäki, A., 2005: The economic impact of ageing populations in the EU25 Member States. European Economy, Economic Papers 236, December, Brussels, 57 p.

Deci, E.L., Ryan, R.M., 2000: The »what « and »why« of goal pursuits: human needs and the self-determination of behaviour. Psychological Inquiry 11(4): 227-268. https://doiorg/10.1207/S15327965PLI1104_01

El Fassi, M., Bocquet, V., Majery, N., Lair, M.L., Couffignal, S., Mairiaux, P., 2013: Work ability assessment in a worker population: comparison and determinants of Work Ability Index and Work Ability score. BMC Public Health 13(1): 1-10. https:// doi.org/10.1186/1471-2458-13-305

Erikson, M., Lindroos, O., 2014: Productivity of harvesters and forwarders in CTL operations in northern Sweden based on large follow-up datasets. International Journal of Forest Engineering 25(3): 179-200. https://doi.org/10.1080/14942119.2014. 974309

European Commission, 2017: The 2018 ageing report. Underlying assumptions \& projection methodologies. Institutional Paper 065, November, Brussels, 240 p. https://doi-org/ $10.2765 / 286359$

Eurostat statistical books, 2020: Ageing Europe-looking at the lives of older people in the EU - 2020 edition. Luxembourg: Publications Office of the European Union, $184 \mathrm{p}$.

Gellerstedt, S., 2002: Operation of the single-grip harvester: motor-sensory and cognitive work. International Journal of Forest Engineering 13(2): 35-47. https://doi.org/10.1080/14942 119.2002.10702461 
Gerasimov, Y., Sokolov, A., 2014: Ergonomic evaluation and comparison of wood harvest systems in Northwest Russia. Applied Ergonomics 45(2): 318-338. https://doi.org/10.1016/j. apergo.2013.04.018

Gröhn, I., Rekola, L., 2017: Tuliko onni puun takaa? Yhteistoiminnallisesti työhyvinvointia ja tuottavuutta kehittämässä metsä- ja sote-alalla. Metropolia Ammattikorkeakoulu.

Hakanen, J., 2011: Työn imu. Työterveyslaitos (Finnish Institute of Occupational Health), Tampere, Finland; 153 p.

Hakanen, J. 2004: From burnout to engagement: in the core and on the fringes of work-related well-being research. Työterveyslaitos (Finnish Institute of Occupational Health), Työ ja ihminen Tutkimusraportti 27, Helsinki, Finland, 294 p.

Hakanen, J., Peeters, M., Perhoniemi, R., 2011: Enrichment processes and gain spirals at work and at home: a 3-year crosslagged panel study. Journal of Occupational and Organizational Psychology 84(1): 8-30. https://doi-org/10.1111/ j.20448325.2010.02014.x

Hakanen, J. Lindbohm, M-L., 2008: Work engagement among breast cancer survivors and their referents: The importance of optimism and social resources at work. Journal of Cancer Survivorship 2(4): 283-295. https://doi-org/10.1007/s11764-0080071-0

Hakanen, J., Bakker, A.B., Schaufeli, W.B., 2006: Burnout and work engagement among teachers. Journal of School Psychology 43(6): 495-513. https://doi-org/10.1016/j.jsp.2005.11.001

Hakkila, P., Kanninen, K., Mäkinen, P., 1989: Metsäkoneyrittäjän henkilökuva. In Metsäkoneurakoitsija, Koneurakoitsijain liitto, Helsinki, Finland 1, 52-73.

Hartsela, P., 1990: Work postures and strain of workers in Nordic forest work: A selective review. International Journal of Industrial Ergonomics 5(3): 219-226. https://doiorg/10.1016/0169-8141(90)90058-A

Heinikoski, S., Mehtälä, I., 2016: Vitality for forest machine drivers (Vireyttä metsäkoneenkuljettajan työpäivään). Oulu University of Applied Sciences, Oulu, 68 p.

Häggström, C., 2015: Human factors in mechanised cut-tolength forest operations. Acta Universitas Agricultureae Sueciae, Doctoral thesis No. 2015: 59, Faculty of Forest Sciences, Swedish University of Agricultural Sciences, Umeå, 77 p.

Ilmarinen, J., 2009: Work ability-a comprehensive concept for occupational health research and prevention. Scandinavian Journal of Work, Environment \& Health 35(1): 1-5.

Ilmarinen, J., 2007: The work ability index (WAI). Occupational Medicine 57(2): 160. https://doi-org/10.1093/occmed/kqm008

Ilmarinen, J., 2006: Towards a longer and better working life: a challenge of work force ageing. Medicina del Lavoro 97(2): 143-147.

Ilmarinen, J., 1991: The aging worker. Scandinavian Journal of Work, Environment \& Health 17(1): 1-141.

Ilmarinen, J., Tuomi, K., 2004: Past, present and future of work ability: proceedings of the $1^{\text {st }}$ international symposium of work ability: 5-6 September 2001 Tampere, Finland. People and Work Research Reports, Finnish Institute of Occupational Health, Helsinki, 168 p.
Ilmarinen, J., Tuomi, K., 1992: Work ability of aging workers. Scandinavian Journal of Work, Environment \& Health 18(2): 8-10.

Jack, R., Oliver, M., 2008: A review of factors influencing whole-body vibration injuries in forestry mobile machine operators. International Journal of Forest Engineering 19(1): 5165. https://doi-org/10.1080/14942119.2008.10702560

Jiroušek, R., Klvač, R., Skoupý, A., 2007: Productivity and costs of the mechanised cut-to-length wood harvesting system in clear-felling operations. Journal of Forest Science 53(10): 476482. https://doi.org/10.17221/2088-JFS

Juhanko, J., Jurvansuu, M., Ahlqvist, T., Ailisto, H., Alahuhta, P., Collin, J., Halen, M., Heikkilä, T., Kortelainen, H., Mäntylä, M., Seppälä, T., Sallinen, M., Simons, M., Tuominen, A., 2015: Suomalainen teollinen internet - haasteesta mahdollisuudeksi, taustoittava kooste (Industrial internet transforms Finland's challenge into opportunities: background synthesis). ETLA Raportit No 42, 66 p.

Juntunen, M., 2015: Development needs in human resources management in the forest machine contracting industry. University of Applied Sciences, Kajaani, Finland, 116 p.

Kanninen, K., 1993: Sisäisten mallien teoria hakkuutyötapaturmien selittäjänä (Theory of internal models in explaining logging accidents). Folia Forestalia 817, The Finnish Forest Research Institute, Helsinki, $49 \mathrm{p}$.

Katzmarzyk, P.T., Church, T.S., Craig, C.L., Bouchard, C., 2009: Sitting time and mortality from all causes, cardiovascular disease, and cancer. Medicine and Science in Sports and Exercise 41(5): 998-1005. https://doi.org/10.1249/MSS.0b013e3181930355

Kettunen, O., 2015: Effects of physical activity and fitness on the psychological wellbeing of young men and working adults: associations with stress, mental resources, overweight and workability. Doctoral thesis, University of Turku, Turku. Annales universitatis Turkuensis, ser. D, Medica- Odontologica, 0355-9483; 1161, 103 p.

Kloimüller, I., Karazman, R., Geissler, H., KarazmanMorawetz, I., Haupt, H., 1999: The relation of age, work ability index and stress-inducing factors among bus drivers. International Journal of Industrial Ergonomics 25(5): 497-502. https://doi.org/10.1016/S0169-8141(99)00035-9

Koponen, P., Borodulin, K., Lundqvist, A., Sääksjärvi, K., Koskinen, S., 2018: Health, functional capacity and welfare in Finland - FinHealth 2017 study. National Institute for Health and Welfare (THL), Report 4/2018, 236 p.

Kuoppala, J., Lamminpää, A., Husman, P., 2008: Work health promotion, job well-being, and sickness absences-a systematic review and meta-analysis. Journal of Occupational and Environmental Medicine 50(11): 1216-1227. https://doi. org/10.1097/JOM.0b013e31818dbf92

Kääriäinen, R., 2017: The role of a forest machine driver in a forest machine company. University of applied sciences, Finland, $49 \mathrm{p}$.

Lappalainen, K., Manninen, P., Räsänen, K., 2017: Association among sociodemograhic factors, work ability, health behavior, and mental health status for young people after prolonged unemployment. Workplace Health \& Safety 65(2): 65-73. https://doi-org.ezproxy.uef.fi:2443/10.1177/ 2165079916653767 
Lagerstrom, E., Magzamen, S., Brazile, W., Rosecrance, J., 2019: Active surveillance of musculoskeletal disorder symptoms in the development of safety interventions for professional loggers. Safety 5(2): 23. https://doi.org/10.3390/safety5020023

Landekić, M., Martinić, I., Bakarić, M., Šporčić, M., 2013: Work ability index of forestry machine operators and some ergonomic aspects of their work. Croatian Journal of Forest Engineering 34(2): 241-254.

Malinen, J., Taskinen, J., Tolppa, T., 2018: Productivity of cutto-length harvesting by operators' age and experience. Croatian Journal of Forest Engineering 39(1): 15-22.

Monteiro, M.S., Ilmarinen, J., Corrêa Filho, H.R., 2006: Work ability of workers in different age groups in a public health institution in Brazil. International Journal of Occupational Safety and Ergonomics 12(4): 417-427. https://doi.org/10.1080 /10803548.2006.11076703

Mylek, M., Schirmer, J., 2015: Beyond physical health and safety: Supporting the wellbeing of workers employed in the forest industry. Forestry 88(4): 391-406. https://doi.org/10.1093/ forestry/cpv011

Nieminen, A., 2015: Resurssitehokas puunkorjuu. Tapion raportteja nro 5, Helsinki, 34 p.

Nurminen, T., Korpunen, H., Uusitalo, J., 2009: Applying the activity-based costing to cut-to-length timber harvesting and trucking. Silva Fennica 43(5): 847-870. https://doi.org/10.14214/ sf.177

Ovaskainen, H., 2009: Timber harvester operators' working technique in first thinning and the importance of cognitive abilities on work productivity. Dissertationes forestales 79: 62 p. https://doi.org/10.14214/df.79

Ovaskainen, H., Heikkilä, M., 2007: Visuospatial cognitive abilities in cut-to-length single-grip timber harvester work. International Journal of Industrial Ergonomics 37(9-10): 771780. https://doi.org/10.1016/j.ergon.2007.06.004

Ovaskainen, H., Pajuoja, H., 2020: Työnjako suomalaisessa puuhuollossa 2020. The division of work in forest sector. Metsätehon raportti 254, Vantaa, Finland, 54 p.

Parzefall, M-R., Hakanen, J., 2010: Psychological contract and its motivational and health-enhancing properties. Journal of Managerial Psychology 25(1): 4-21. https://doi.org/10.1108/ 02683941011013849

Pere, A., Nieminen, A., Turunen, J., Tuure, V-M., Hourunranta, P., Lahdensaari-Nätt, L., 2015: Ennakoinnilla tuottavuutta metsätöihin. Työtehoseuran julkaisuja 421, Nurmijärvi, Finland, 33 p.

Perkiö-Mäkelä, M., Rytkönen, H., Laulainen, S., Peurala, M., Penttinen, J., 2001: Factors contributing to the motivation of forest workers and forest machine operators to remain in gainful employment. LEL Työeläkekassan julkaisuja 38/2001, Helsinki, Finland, $77 \mathrm{p}$.

Pohjonen, T., 2001: Perceived work ability of home care workers in relation to individual and work-related factors in different age groups. Occupational Medicine 51(3): 209-217. https:// doi-org/10.1093/occmed/51.3.209

Puttonen, S., Hasu, M., Pahkin, K., 2016: Työhyvinvointi paremmaksi. Keinoja työhyvinvoinnin ja työterveyden kehittämiseksi Suomalaisilla työpaikoilla. Työterveyslaitos (Finnish Institute of Occupational Health), Helsinki, Finland, 36 p.
Purfürst, F.T., 2010: Learning curves of Harvester operators. Croatian Journal of Forest Engineering 31(2): 89-97.

Radkiewich, P., Widerszal-Bazyl, M., 2005: Psychometric Properties of Work Ability Index in the Light of Comparative Survey Study. International Congress Series 1280: 304-309. https:// doi-org/10.1016/j.ics.2005.02.089

Rauramo, P., 2009: Työhyvinvoinnin portaat, työkirja. Työturvallisuuskeskus TTK, Finland, 2-3.

Rautio, M., Michelsen, T., 2013: WAI: how to use the Work Ability Index questionnaire, $2^{\text {nd }}$ ed.; TTL (Finnish Institute of Occupational Health), Helsinki, Finland, 24 p.

Rehn, B., Bergdahl, I.A., Ahlgren, C., From, C., Järvholm, B., Lundström, R., Nilsson, T., Sundelin, G., 2002: Musculoskeletal symptoms among drivers of all-terrain vehicles. Journal of Sound and Vibration 253(1): 21-29. https://doi-org/10.1006/ jsvi.2001.4247

Rekilä, M., Räsänen, T., 2008: Laajavastuinen yrittäjyys puunhankinnassa. Metsätehon katsaus nro 33/2008, Metsäteho Oy, Helsinki, Finland, 4 p.

Repo, S., Ravantti, E., Pääkkönen, R., 2015: Johda tuottavasti. Opas työhyvinvoinnin ja tuottavuuden lisäämiseksi esimiestyön keinoin. TTL (Finnish Institute of Occupational Health), Helsinki, Finland, 46 p.

Robert J.J., Michele, O., 2008: A review of factors influencing whole-body vibration injuries in forestry mobile machine operators. International Journal of Forest Engineering 19(1): 5165. https://doi.org/10.1080/14942119.2008.10702560

Rytkönen, H., Hyttinen, M., Hänninen, K., Sorvari, S., Juntunen, J., 2009: Working conditions, health and working capacity among workers on the fields of construction, forestry, agriculture and dockwork (3T survey) in 1998, 2001, 2004 and 2008. Studies of Etera Mutual Pension Insurance Company, 7/2009, Finland, 136 p.

Schaufeli, W.B., Taris, T.W., Bakker, A., 2006: Dr. Jekyll and Mr. Hide: On the differences between work engagement and workaholism. In Research companion to working time and work addiction, Edit. Burke, R.J.; Edward Elgar: Cheltenham, UK, 193-217.

Schaufeli, W.B., Salanova, M., González-Romá, V., Bakker, A., 2002: The measurement of engagement and burnout: a two sample confirmatory factor analytic approach. Journal of Happiness Studies 3(1): 71-92. https://doi.org/10.1023/ A:1015630930326

Serban, A.C., 2012: Aging population and effects on labour market. Procedia Economics and Finance 1: 356-364. https:// doi.org/10.1016/S2212-5671(12)00041-X

Shemeikka, R., Aho, S., Jokinen, E., Järnefelt, N., Kaakinen, M., Kivimäki, R., Korkeamäki, J., Mertala, S., Mäkiaho, A., Parkkinen, M., Pitkänen, S., Terävä, K., Vuorento, M., 2017: Prolonging working careers requires cooperation and a sense of community. Prime Minister's Office: Helsinki, Finland, 249 p. Siukola, A., Pursio, H., Liukkonen, P., Vänni, K., Uitti, J., Liukkonen, V., Kosonen, H., Nygård, C.H., 2018: Työhyvinvointi puunkorjuuyritysten menestymisen tukena, työraportteja 101/2018. Tampereen Yliopisto: Tampere, Finland, 77 p.

Skirbekk, V., 2004: Age and individual productivity: a literature survey. Vienna yearbook of population research; Austrian Academy of Sciences Press, 2: 133-153. 
Skirbekk, V., Loichinger, E., Weber, D., 2011: Variation in cognitive functioning as a refined approach to comparing aging across countries. Proceedings of the national academy of sciences of the United States of America 109(3): 770-774. https:// doi.org/10.1073/pnas.1112173109

Tuomi, K., 1997: Eleven-year follow-up of aging workers. Scandinavian Journal of Work, Environment and Health 23(1): $1-71$.

Tuomi, K., Luostarinen, T., Ilmarinen, J., Klockars, M., 1991: Work load and individual factors affecting work disability among aging municipal employees. Scandinavian Journal of Work, Environment and Health 17(1): 94-98.

Tynkkynen, M., 2001: Assessing harvester operators' mental workload using continuous ECG recording technique. International Journal of Cognitive Ergonomics 5(3): 213-219. https:// doi.org/10.1207/S15327566IJCE0503_4

Uusitalo, J., 2005: A framework for CTL-method-based wood procurement logistics. International Journal of Forest Engineering 16(2): 37-46. https://doi.org/10.1080/14942119.2005.10 702512

Van den Berg, T.I.J., Elders, L.A.M., de Zwart, B.C.H., Burdorf, A., 2009: The effects of work related and individual factors on the work ability index: A systematic review. Occupational and
Environmental Medicine 66(4): 211-220. https://doi. org/10.1136/oem.2008.039883

Van den Berg, T.I.J., Alavinia, S.M., Bredt, F.J., Lindeboom, D., Elders, L.A.M., Burdorf, A., 2008: The influence of psychosocial factors at work and life style on health and work among professional workers. International Archives of Occupational and Environmental Health 81(8): 1029-1036. https://doi. org/10.1007/s00420-007-0296-7

Vihottula, M., 2010: Harvester drivers' job satisfaction. University of Applied Sciences, North Karelia, Finland, 49 p.

Vänni, K., Virtanen, P., Luukkala, T., Nygård, C.H., 2012: Relationship between perceived work ability and productivity loss. International Journal of Occupational Safety and Ergonomics 18(3): 299-309. https://doi.org/10.1080/10803548.2012. 11076946

Väätäinen, K., Ikonen, T., Ala-Ilomäki, J., Sirén, M., Lamminen, S., Asikainen, A., 2012: Kuljettajaa opastavat älykkäät järjestelmät ja niiden käyttö koneellisessa puunkorjuussa. Finnish Forest Research Institute, Working Papers of the Finnish Forest Research Institute 223, 40 p.

de Zwart, B., Frings-Dresen, M., 2002: Test-retest reliability of the Work Ability Index questionnaire. Occupational Medicine 52(4): 177-181. https://doi.org/10.1093/occmed/52.4.177

(C) 2021 by the authors. Submitted for possible open access publication under the terms and conditions of the Creative Commons Attribution (CC BY) license (http://creativecommons.org/licenses/by/4.0/).

Received: April 23, 2020

Accepted: January 22, 2021
Authors' addresses:

Heli Kymäläinen *

e-mail: heli.kymalainen@uef.fi

School of Forest Sciences

Faculty of Science and Forestry

University of Eastern Finland

P.O. Box 111

80101 Joensuu

FINLAND

Juha Laitila, PhD

e-mail: juha.laitila@luke.fi

Kari Väätäinen, PhD

e-mail: kari.vaatainen@luke.fi

Natural Research Institute Finland

Yliopistokatu 6 B

80100 Joensuu

FINLAND

Jukka Malinen, PhD

e-mail: jukka.malinen@metsateho.fi

Metsäteho Oy

01300 Vantaa

FINLAND

* Corresponding author 